\title{
WORLD HISTORY
}

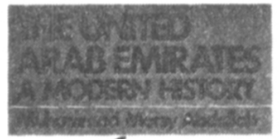

n P. topis
The United Arab Emirates

A Modern History MUHAMMAD MORSY 'ABDULLAH

Stressing aspects of the political history of the Arabian Gulf that have been neglected by non-Arab historians, this enlightening book traces the impact of British policy on the region from 1892 until the British withdrawal in 1971 .

September 1978. 320pp. $\$ 21.50$.

\section{Queen's Rebels}

\section{Ulster Loyalism in Historical Perspective DAVID MILLER}

By exploring the anomalies that underlie the character of the Ulster Protestant community, this book delineates the nature of the Northern Ireland problem more clearly than any previous work. It is provocatively and vigorously written, and explains the ideology of Ulster loyalism in its historical context. October 1978. 180pp. Bibl. Index. \$22.00.

\section{China}

\section{The Impact of the Cultural Revolution} BILL BRUGGER, editor

Analyzing the sweeping changes in China, these challenging essays provide a solid basis for interpreting recent events. Of central concern to all of the contributions are the vital issues raised by the Cultural Revolution.

September 1978. 320pp. Intro. $\$ 19.50$.

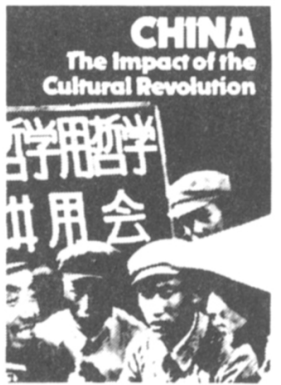




\section{New Titles in British History \\ Britain in the Early Nineteenth Century}

StMartinis Press

A. D. Harvey

"It will fill a glaring gap in our knowledge of early nineteenth century history..."

"its coverage of the period is comprehensive... an extremely good piece of historic writing, and well presented...."

G. E. Mingay

This is the first comprehensive and integrated history of Britain during the two crucial opening decades of the nineteenth century-years of struggle against Napoleon, of intense political conflict, and of major economic change.

\section{Independent Colliers}

\section{The Coal Miner as Proletarian Reconsidered}

Royden Harrison, editor

In a closely related series of studies of coal mining communities in nineteenth century Britain, the contributors challenge the conventional view of the miner as the "archetypal proletarian." These essays emphasize the experience of individuals and make new use of economic and demographic evidence to reconstruct the lives of mining communities. They refute Adam Smith's declaration that colliers were indistinguishable in point of skill from common laborers and reveal the experience of mining communities to be far more varied and complex than has been previously realized.

1978 ISBN $\quad 0-312-41290-8 \quad 200$ pages $\$ 18.95$

\section{Wilberforce}

John Pollock

The campaign of William Wilberforce to abolish the slave trade is the predominant concern of this book. Drawing on a mass of new manuscript material, John Pollock discloses the dramatic inside story of the final stages of the slave trade's aboliton.

1978 ISBN 0-312-87942-3 368 pages, illustrated $\$ 16.95$

\section{The Twentieth Century, 1880-1939}

Paul Hayes

Modern British Foreign Policy Series

This volume analyzes the years when Britain lost her status as the world's leading power. Protessor Hayes explores the increasing constraints placed upon British diplomatic strategy by changing political and economic climates and argues that politicians, diplomats, and even the British public accelerated the country's diplomatic decline by their common lack of faith in Britain's ability to make and execute appropriate foreign policy decisions.

1978 ISBN 0-312-82409-2 340 pages $\$ 15.95$

\section{David Livingstone \\ The Dark Interior}

Oliver Ransford

David Livingstone, though a contemporary hero to the Victorian British, was a lonely man and one of the most elusive figures of his age. In his new biography, Oliver Ransford probes the personality of this solitary explorer, tracing his severe moodiness and his difficulty in working with other Europeans to a manic-depressive disorder which afflicted several members of the Livingstone family. and finding explanations for his intense fascination with African culture in the missionary zeal instilled by his nonconformist upbringing.

1978 ISBN 0-312-18379-8 300 pages, illustrated \$18.95

\section{Inside Asquith's Cabinet} From the Diaries of Charles Hobhouse

Edward David, editor

"It is a happy circumstance that Hobhouse's diaries, originally running to 300,000 words, have now been unearthed and reduced to publishable form. It is even happier that they have been edited with such style and skill by Edward David..."

$T L S$

"Hobhouse's diaries covering the years 1893-1898 and 1904-1915 provide an accurate and unique view of many familiar personalities and events in early 20 th-Century politics... The editor has done a thorough job of introducing the material identifying personages, and verifying the facts. The resulting book will be both useful to the historian and fascinating to the general reader." Librany Journal

1978 ISBN 0-312.41868-X 295 pages $\$ 16.95$ 


\section{The Development of the British Welfare State, 1880-1975}

\author{
J. R. Hay
}

Documents of Modern History Series

With the publication of this documentary survey, the student of modern British history will be able at last to trace the historical development of the British welfare state-in the words of the people involved where appropriate-and in the author's fucid commentaries in other instances. The book clearly illustrates the ambivalence of members of the working class toward social reform and demonstrates that their perception of social problems was, throughout the period, a good deal more complex and sophisticated than earlier historians understood.

$1978 \quad$ ISBN 0-312-19749-7 250 pages $\$ \mathbf{\$ 1 8 . 9 5}$

\section{Leonard Woolf \\ A Polltical Biography}

Duncan Wilson

Leonard Woolf, a man deeply committed to politics and social problems as well as a literary figure of major importance had a signiticant influence on the development of the British Left in the early twentieth century. In this new biography Duncan Wilson traces the course of Leonard Woolf's political life and provides a masterly precis of the historical background against which Leonard Woolf's work has to be seen.

1978 ISBN 0.312-48001-6 288 pages $\$ 18.50$

\section{Social Reform in England, 1780-1880}

John Roach

John Roach views social history primarily as the evolution of ideas under the pressure of events. He argues that the changes that produced the social pattern of nineteenthcentury England began considerably earlier than the legislation of the 1830 's and was maintained by a certain balance between individualistic philosophy and state power, which held until the 1880 's.

1978 ISBN $0.312 .73481-6 \quad 260$ pages $\$ 22.50$

\section{The Sweated Trades \\ Outwork in Nineteenth-century Britain}

Duncan Bythell

".... an excellent discussion of a much neglected part of the industrial revolution story... an authoritative work which will not be quickly superseded." G. E. Mingay

Duncan Bythell's comprehensive study traces for the first time the disappearance of the domestic system of massproduction, exploring the reasons for its orolonged tenacity as well as the reasons for its eventual decline.

$1978 \quad$ ISBN 0-312-77999-2 272 pages $\$ 21.50$

\section{Stuart England}

\section{J. P. Kenyon}

In this interpretive survey, J. R. Kenyon addresses questions about Parliament's legislative role and character, England's prosperity, Stuart self-interest, and propriety in policy making. He demonstrates that the central issues for the seventeenth century were those of power, physical authority, and the ability to command obedience.

1978 ISBN 0-312-76909-1 380 pages $\$ 12.95$

\section{Trends in British Politics Since 1945}

Chris Cook and John Ramsden, editors

The ten general elections and eight prime ministers of the past three decades have effected fundamental changes in the major areas of British domestic politics. This timely collection of original essays includes articles on constitutional development, the Conservative and Labour parties and the challenge of the Liberal and Nationalist parties. the role of trade unions, the economic debate, and the progress of nationalization in industry.

1978 ISBN 0-312-81754-1 200 pages $\$ 17.95$

To order these books for your library, at a $20 \%$ professional discount, please write: 


\section{THE EIGHTEENTH CENTURY}

Theory and Tnterpretation

Published Winter, Spring and Autumn

by Texas Tech University

Editors

Jeffrey R. Smitten

Joel C. Weinsheimer

Editorial Board

A. Owen Aldridge

Paul K. Alkon

Michael Fried

Alexander Gelley

Josué Harari

J. Jean Hecht

C. P. Ives

Isaac Kramnick

Lawrence I. Lipking

Christie V. McDonald

Earl Miner

Walter Moser

Mark Poster

Ralph W. Rader

Ronald C. Rosbottom

G. S. Rousseau

Sheldon Sacks

Rémy G. Saisselin

Hayden White
Selected Contents of Volume 20 (1979)

Arthur Cash on Sterne Criticism

Murray Cohen on 18th-Century Literature and Modern Methodology

John Dixon Hunt on Turner

Lawrence Lipking on Burke

Christie McDonald on Derrida's Rousseau

Michael Murray on Heidegger and Hölderlin

Frank O'Gorman on Political History

David Pfeifer on Berkeley and Peirce

Roland Posner on Tristram Shandy and Semiotics

Mark Poster on Sartre, Althusser, and 1789

Gregory Ulmer on the DeMan-Derrida Argument

Subscriptions to $\mathrm{EC}: \mathrm{T} \& \mathrm{I}$ are $\$ 8.00$ per year.

Correspondence should be addressed to:

The Editors

The Eighteenth Century:

Theory and Interpretation

P.O. Box 4530

Texas Tech University

Lubbock, Texas 79409

(formerly Studies in Burke and His Time) 


\section{from Scholarly Resources \\ The House of Commons Sessional Papers of the Eighteenth Century edited by Sheila Lambert}

"One of the most significant projects of recent years ... it clearly supercedes both the so-called Abbot Collection .... and the fifteen volumes Reports from Committees of the House of Commons 1715-1801."

“. . . for every research library it should become an essential holding."

- The British Studies Monitor

“... easily eclipsing the old 19th-century selections of the Abbot Collection. There has never been and there will never be a collection quite as complete and indispensable." - Choice

"A facsimile reproduction of the House of Commons sessional papers of the eighteenth century in itself constitutes a valuable service to historians of the period, whatever their particular interest. But it is still more of service when it comes with two introductory volumes as excellent as Sheila Lambert's."

-Paul Langford

Times Literary Supplement

SECTION I - GEORGE I AND II

19 folio volumes plus list

LC 74-33160

ISBN 0-8420-2014-4
$\$ 1,630$ current $\$ 1,800$ after Dec. I

Scholarly Resources Inc.

isos Pennsylvania Avenue - Wilmingron. Delaware 19806

Telephone: $302-054 \cdot 7713$

ISBN 0-8420-2016-0
SECTION II- GEORGE III

126 folio volumes plus list

$\$ 10,180$ current

LC 74-33160 $\$ 11,200$ after Dec.

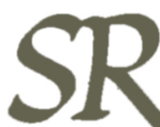

